\title{
ファロー四徴術後遠隔期における不整脈と運動能の検討
}

\author{
込山修* 小佐野 満** 菅谷明則** 田口暢彦** \\ EVALUATION OF LATE ARRHYTHMIA AND EXERCISE
PERFORMANCE IN PATIENTS AFTER INTRACARDIAC
REPAIR OF TETRALOGY OF FALLOT
}

\author{
Osamu Komiyama, Mitsuru Osano, Akinori Sugaya \\ and NobUhiko TAgUCHI
}

\begin{abstract}
Treadmill exercise test and cold water face-immersion test were performed in 50 patients with tetralogy of Fallot at a mean age of 11.9 years, an average of 8.2 years after intracardiac repair. Cardiac catheterization was also performed in 45 patients $0.5-11$ years after the repair.

Exercise performance and results of catheterization were compared in patients with and without ventricular premature contraction (VPC). In $22(44 \%)$ of the 50 patients, VPC was induced by treadmill and/or cold water face-immersion test. Compared with the other 28 patients, the patients who had VPC during the tests, 1 ) were older (13.6 versus 10.6 years, $\mathrm{p}<$ $0.05, \mathrm{t}$-test) and were tested at a longer interval after repair of tetralogy of Fallot (9.5 versus 7.3 years, $\mathrm{p}<0.05), 2$ ) showed no difference in the results of catheterization, and 3 ) had lower exercise performance.

Cold water face-immersion test is therefore considered to be useful for evaluation of patients after intracardiac repair of tetralogy of Fallot.
\end{abstract}

(Jpn. J. Phys. Fitness Sports Med. 1990, $39: 256 \sim 261$ )

key words : tetralogy of Fallot, ventricular premature contraction, treadmill exercise test, diving reflex

\section{I. 粕}

近年, 心䐬外科手術および術前後管理の進歩に より,ファロー四微心内修復術の成績は飛躍的に 向上し，長期生存例が増加している. その反面， 術後遠隔期に打ける心室性不整脈の出現やそれに 伴ら突然死が問題となっている ${ }^{5,8)}$. また, 術後患 児の運動能については最大仕事量の低下がいわれ ており ${ }^{9,13)}$ ，不整脈のある患児の運動能が有意に 劣るとの報告もみられる ${ }^{20)}$. 心室性不整脈の有無 により運動能や心機能に差があるか否かを評価す ることは術後管理に有用と考えられる.

通常の運動負荷では交感神経系緊張によるスト
レスがもたらされそれれより心室性不整脈が誘 発される場合があるが，潜水や冷水浴のような迷 走神経緊張時にも心室性不整脈が出現することが 報告されている2,16)。

そこで我々は, 術後患者にトレッドミル運動負 荷試験と迷走神経を緊張させる冷水顔面浸水負荷 試験 (cold water face-immersion test)を行い, 心 室性期外収縮 (VPC) 誘発の有無と運動能および 心臓カテーテル検查成績とを比較検討した。

\section{II. 対象亡方法}

対象はファロー四徵心内修復術後の患者 50 例 で, 男子 25 例, 女子 25 例, 年齢は 5 歳から 21 歳

\footnotetext{
* B \& G 財団健康管理相談室 干135 東京都江東区深川1-6-3

**慶礁義塾大学医学部小児科 干160 東京都新宿区信濃町35

$B \& G$ Foundation Health Consultation Office, Fukagawa 1-6-3, Kotoku Tokyo, 135 Department of Pediatrics, School of Medicine, Keio University, Shinanomachi 35, Shinjuku-ku Tokyo 160
} 
$(11.9 \pm 4.3$ 歳, 平均值 $\pm S D)$, 心内修復術を 1.3 歳 から 9.2 歳( $3.7 \pm 1.6$ 歳)で受け, 術後 0.9 年から 19 年 $(8.2 \pm 3.9$ 年)を経過している. 全例ジギタリス 等の薬剤は服用していない.50例中45例に術後平 均 2.1 年で行った心蔵カテーテル検査では, 右室 収縮期圧平均 $44.4 \pm 14.4 \mathrm{mmHg}$, 胸部 $\mathrm{X}$ 線上心胸 郭比は平均 $54.4 \pm 5.1 \%$ であった.

トレッドミル運動負荷試験はフクダ䉓子社製 MAT-2000を用い, Bruce protocol ${ }^{11}$ に従い症候 性限界までの歩行と回復期 9 分間の坐位安静とし た. Mason-Likar 変法 ${ }^{18)}$ で心電戝電極を装着し て検査中モニターにより不整脈の有無を常時監視 し, 不整脈出現時および負荷前と負荷中, 後 3 分 毎に12誘導心電図を記録した。同時に日本電気三 栄社製 391 エアロビクスプロセッサーにより酸素 消費量を30秒每に測定した，運動耐容能の指標と 乙て運動耐久時間, 最大心拍数と最大酸素消費量 を記録し，それとともに酸素消費量一心拍数回㷌 直線勾配を算出した。

冷水顔面浸水負荷試験は， $4{ }^{\circ} \mathrm{C}$ の冷水に顔面を つけて30秒を目標にできるだけ長く息こらえをす る方法とし，検查中の心電図を記録した．

心臓カテーテル検查は 50 例中 45 例に術後平均 2.1 年 $(0.5$ 年から 11 年) で行った。また，胸部 $\mathrm{X}$ 線 から心胸郭比を求めた.

両負荷試験の一方あるいは両方で VPC が誘発
された群と非誘発群とに患者を分け，両群で各パ ラメーターを比較検討した．有意差検定にはstudents' t-test を用い, $\mathrm{p}<0.05$ を有意とした。

\section{III. 成}

\section{綪}

\section{A. 安静時 12 誘道心雷図}

VPC を 50 例中 5 例 $(10 \%)$ に認め, すべて単発 例であった．その他の不整脈として上室性期外収 縮 (SVPC) 1 例，第 1 度房室ブロック 3 例，房室 解離 1 例を認めた。

完全右脚ブロックは36例 $(72 \%)$ にみられ，その うち左軸偏位の合併は 2 例であった．不完全右脚 ブロックが11例にみられた。

B. トレッドミル運動負荷試験 (Table 1) 50 例中19例(38\%)で VPC が誘発され, Lown 分類では I 度 13 例, II 度 3 例, III 度 2 例, $\mathrm{N}$ a 度 1 例であった. VPC の出現時期についてみると， 負荷前(安静時)にVPC を5 例に認め, 負荷中は 6 例, 負荷直後の回復期には計16例に VPC を認 めた(Table 2). 負荷中にみられた VPC は基礎心 拍数 150 /分以上で全例消失した.

その他 SVPC が7例に主として回復期に出現 し，そのうち 1 例に short run を認めた。

C. 冷水顔面浸水負荷試験 (Table 1)

顔面浸水時間は平均 $17.2 \pm 9.9$ 秒と短かったが, VPC を 8 例 $(16 \%)$ に認めた。そのらち 3 例は安

Table 1. Arrhythmias during treadmill and face immersion test

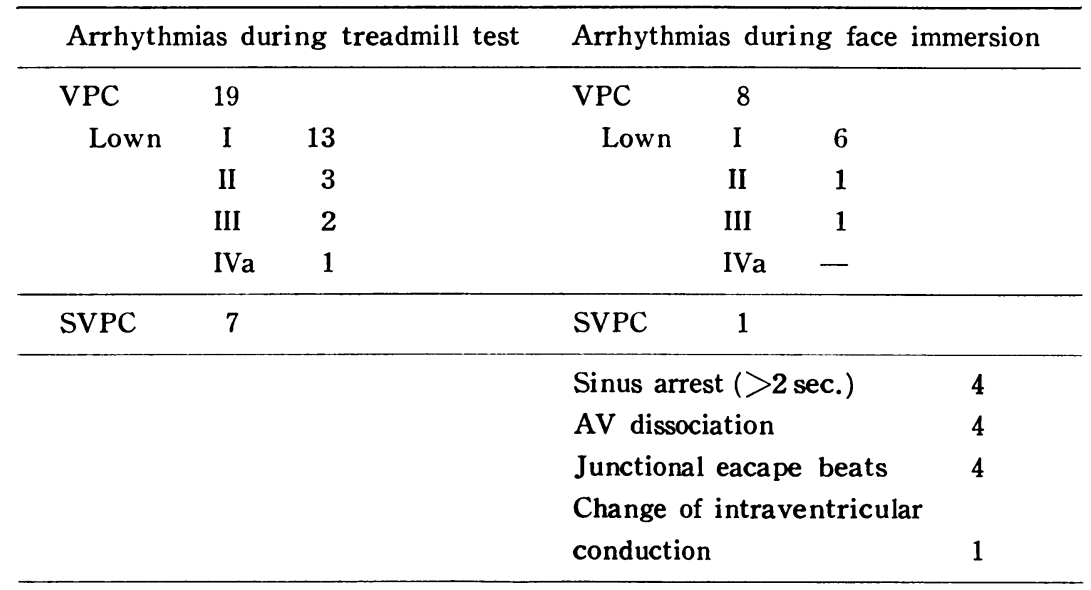

VPC : Ventricular premature contraction.

SVPC : Supraventricular premature contraction. 
Table 2. Timing of VPC during treadmill test

\begin{tabular}{|c|c|c|}
\hline Before exercise & During exercise & Recovery period \\
\hline ? & ? & P \\
\hline ? & $\varphi_{1}$ & \\
\hline \multirow[t]{4}{*}{ O P O } & & 0,0 \\
\hline & $\bigcirc \bigcirc$ & \\
\hline & 0,0 & 0,0 \\
\hline & & 0000000000 \\
\hline
\end{tabular}

静時技よびトレッドミル運動負荷時にはVPC は みられなかった．多くは単発であったが，1例に 頻発を, 1 例に二連発を認めた.

その他の不整脈として SVPC 1 例, 2 秒以上の 洞停止(最大 3.2 秒) 4 例, 房室解離 4 例, 房室結 節補充調律 4 例, 心室内伝導の変化 1 例を認めた.

\section{VPC 唀発群之非誘発群の比較}

トレッドミル運動負荷によるVPC 誘発19例と 顔面浸水負荷でのみ誘発された 3 例を合わせた 22 例をVPC 誘発群とし, 非誘発群と比較した。

1. 手術年龄, 検查時年龄, 術後経過年数 (Table 3)

VPC 誘発群と非誘発群の手術年龄はそれぞれ $4.1 \pm 1.9$ 歳, $3.4 \pm 1.3$ 歳で, 有意差はみられなか った。検查時年龄は $13.6 \pm 4.4$ 歳, $10.6 \pm 3.7$ 歳 $(\mathrm{p}<$ 0.05 ), 術後経過年数は $9.5 \pm 4.3$ 年, $7.3 \pm 3.4$ 年 $(\mathrm{p}<$ 0.05) と誘発群で大きく, 有意差を認めた.

2. 運動能 (Table 4)

最大心拍数が 180 /分以上に達した症例は 22 例

Table 3. Age versus VPCs during treadmill and/or face immersion test

\begin{tabular}{lrrr}
\hline & $\begin{array}{c}\mathrm{VPC}(+) \\
\mathrm{N}=22\end{array}$ & $\begin{array}{c}\mathrm{VPC}(-) \\
\mathrm{N}=28\end{array}$ & $\mathrm{p}$ \\
\hline Age at repair of & $4.1 \pm 1.9$ & $3.4 \pm 1.3$ & $\mathrm{NS}$ \\
TOF $(\mathrm{yr})$ & & & \\
Age at tests (yr) & $13.6 \pm 4.4$ & $10.6 \pm 3.7$ & $<0.05$ \\
Postoperative years & $9.5 \pm 4.3$ & $7.3 \pm 3.4$ & $<0.05$ \\
\hline
\end{tabular}

mean \pm SD. TOF : Tetralogy of Fallot, NS : not significant, $\mathrm{p}$ : probability.
Table 4. Comparison of exercise performance in post-TOF repair patients with VPC and without VPC on treadmill and/or face im. mersion test

\begin{tabular}{lccl}
\hline & $\begin{array}{c}\mathrm{VPC}(+) \\
\mathrm{N}=22\end{array}$ & $\begin{array}{c}\mathrm{VPC}(-) \\
\mathrm{N}=28\end{array}$ & $\mathrm{p}$ \\
\hline Endurance time(min.) & $8.2 \pm 1.6$ & $7.7 \pm 1.6$ & $\mathrm{NS}$ \\
HR max. (beats/min.) & $178 \pm 15$ & $169 \pm 22$ & $\mathrm{NS}$ \\
$\dot{\mathrm{V}} \mathrm{o}_{2} \max$ ( $\left.\mathrm{ml} / \mathrm{kg} / \mathrm{min}.\right)$ & $33.8 \pm 6.2$ & $34.5 \pm 6.4$ & $\mathrm{NS}$ \\
$\Delta \dot{\mathrm{V}}_{2} / \Delta \mathrm{HR}$ & $0.32 \pm 0.08$ & $0.40 \pm 0.10$ & $<0.01$ \\
\hline
\end{tabular}

HR : Heart rate, $\dot{V}_{2}$ : Oxygen uptake.

(44\%)であった. 運動耐久時間, 最大心拍数, 最 大酸素消費量には両群間に明らかな差がなかった が，酸素消費量一心拍数回㷌直線勾配で比較する と, VPC 誘発群の $0.32 \pm 0.08$ に対し, 非誘発群は $0.40 \pm 0.10$ と有意に高値で, 非誘発群の運動耐容 能がより良好と思われる.

\section{3. 心胸郭比}

胸部X線上の心胸郭比はVPC 誘発群 $54.2 \pm$ $0.5 \%$, 非誘発群 $54.6 \pm 4.8 \%$ と有意差は認められ なかった。

4. 心睵カテーテル検査 (Table 5)

VPC 誘発群 19 例, 非誘発群 26 例に行った心 䑏カテーテル検査では, 右室収縮期圧は誘 発群 $41.6 \pm 13.9 \mathrm{mmHg}$, 非誘発群 $46.4 \pm 14.8 \mathrm{mmHg}$ と 差がなく, $60 \mathrm{mmHg}$ 以上の症例もとれぞれ 4 例, 3 例と同程度であった. 右房平均圧, 肺動脈収縮 期圧および右室一肺動脈圧較差にも有意差は認め られなかった。 
Table 5. Comparison of hemodynamic results in post-TOF repair patients with VPC and without VPC on treadmill and/or face immersion test

\begin{tabular}{lccc}
\hline & $\begin{array}{c}\mathrm{VPC}(+) \\
\mathrm{N}=19\end{array}$ & $\begin{array}{c}\mathrm{VPC}(-) \\
\mathrm{N}=26\end{array}$ & $\mathrm{p}$ \\
\hline RA mean (mmHg) & $3.4 \pm 2.8$ & $4.1 \pm 2.7$ & $\mathrm{NS}$ \\
$\mathrm{RVSP}(\mathrm{mmHg})$ & $41.6 \pm 13.9$ & $46.4 \pm 14.8$ & $\mathrm{NS}$ \\
$\mathrm{PASP}(\mathrm{mmHg})$ & $29.0 \pm 10.1$ & $34.4 \pm 13.9$ & $\mathrm{NS}$ \\
$\mathrm{RV}-\mathrm{PA}$ gradient \\
\multicolumn{1}{c}{$(\mathrm{mmHg})$} & $12.4 \pm 12.4$ & $12.0 \pm 10.3$ & $\mathrm{NS}$ \\
\hline
\end{tabular}

RA : Right atrium, RVSP : Right ventricle systolic pressure, PASP : Pulmonary artery systolic pressure.

\section{IV. 考按}

ファロー四徵術後遠隔期における突然死が 1 〜 $4 \%$ 頻度で報告され ${ }^{6,12,19)}$ ，術後の大きな問題 となっている，その原因として，以前は進行性の 房室伝導障害が挙げられ, 右脚兼左脚前枝ブロッ クが危険因子とされていたが22，現在では心室性 不整脈との関連が重要視されている, 運動負荷により出現あるいは悪化するVPC につ いては, 運動制限や抗不整脈の投与が勧められて いる7).

一般に運動負荷は交感神経系を緊張させ，心拍 数を増加させるものであるが, 潜水, 冷水浴など の徐脈をあたらす迷走神経緊張型の負荷でも心室 性不整脈が誘発されることは稀ではなく2,16), 致 死的不整脈によると思われる突然死例も報告され ている ${ }^{17)}$. したがって, 通常の運動負荷とともに 迷走神経緊張時の反応をみることは術後管理の面 から必要と考えられる。

迷走神経刺激の方法として, diving reflex を利 用した冷水顔面浸水負荷が安全かつ確実な刺激が 得られるとされ，発作性上室性頻拍の治療に臨床 上用いられている211. 我々はこの方法をトレッド ミル運動負荷と共に所定の検查にしている.

トレッドミル運動負荷と冷水顔面浸水負荷によ り50例中22例(44\%)で VPC が誘発されたが，非 誘発群と比較すると，検查時年龄は高く，術後経 過年数が有意に長かった.ファロー術後の VPC
発生要因として, 手術部位(特に右室流出路)の洀 痕化や右室心筋の線維化などの影響が報告されて おり ${ }^{3,11)}$ ，術後経過がより長期になるほど VPC の出現頻度が増するのと推測される.また，ファ ロ一四徵の未手術例では低酸素と右室肥大により 右室の線維化が年龄と共に進行し ${ }^{14)}$ ，そのため手 術年㱓が高いほど VPC の頻度が増大すると言わ れている4,15)。今回，手術年龄には差がみられな かったが，対象とした症例のうち6歳以上で手術 を行ったのは 5 例にすぎず, 大半が $2 \sim 4$ 歳に集 中していたためと思われる.

運動能についてみると，運動酎久時間，最大心 拍数および最大酸素消費量はVPC 誘発群と非誘 発群の間に差がみられなかったが，両群の年龄構 成に有意差があること, 最大心拍数が 180/分以上 に達した症例が $44 \%$ と少なく，真の最大酸素消費 量を表していないことなどから単純には比較でき ない，そこで，この点を補正する意味で酸素消費 量一心拍数回㷌直線勾配を両群で比較した. 酸素 消費量は心拍出量(心拍数と一回拍出量との積) と 動静脈酸素較差の積として表され，酸素消費量と 心拍数は良好な直線回帰を示し, その勾配 $\left(\Delta \dot{\mathrm{V}}_{2}\right)$ $\Delta \mathrm{HR})$ は一回拍出量の指標となる.その值が大き いほど循環効率がよいと考えられる. 本田たち ${ }^{101}$ は同勾配 0.3 未満を運動耐容能不良群, $0.3 \sim 0.35$ を境界群， 0.35〜0.45 を普通児群としている.こ れをあてはめると, VPC 誘発群は 0.32 で境界群, 非誘発群は 0.40 で普通児群となり, 誘発群の運動 耐容能はやや劣り，正常下限と考えられる.

従来, VPC 出現症例はVPC を認めない症例に 比し，右室圧が高く血行動態が不良であるといら 報告”と，差がないといら報告 ${ }^{15)}$ がみられるが， 今回の検討では心臓カテーテル検査でみた血行動 態には差がみられず，血行動態の良否に拘らず VPC が出現している.

しかし, VPC の出現そのものが潜在的な心機 能の低下を反映するとの報告もあり ${ }^{201}$, 安静時の 血行動態に差がなくても，運動時に差が出て来れ ば, 運動能に影響するのは当然である. したがっ て,VPC 誘発群に認められた運動能の低下は， この様な安静時と運動時の血行動態の差によるも 
のと思われ, 今後運動時の心機能の評価も必要と 考えられる.

いずれにしてもVPC がどの程度出現すれば病 的と考劣るか，あるいは予後にどの程度影響を及 ぼすのかについては，負荷試験を含めてさらに今 後の検討が必要である.

トレッドミル負荷を含め一般の運動負荷では, 交感神経の緊張により心筋の自動能が六進するた めに VPC が誘発される可能性があり, 特に病的 心睵では誘発率が高くなると思われる．また，運 動時には心筋酸素需要が増すために虚血性心疾患 などでは局所心筋の虚血が起きて不整脈が誘発さ れることも考えられる.

今回のトレッドミル負荷では運動終了後の回復 期早期に VPC が誘発されることが多かったが, 運動による交感神経緊張が急に減衰して交感神経 と迷走神経のバランスが大きく動摇する時期に一 致しており，この時期の VPC の発生機序には自 律神経系の不均衡も関与している可能性が考えら れる.

一方, 冷水顔面浸水負荷では負荷終了直後に VPC の大半が誘発されており，迷走神経緊張が 緩み交感神経緊張が急増する時期に相当する. こ の場合の VPC の誘発にも自律神経系の不均衡の 関与が考えられる.この点ではトレッドミル負荷 直後の VPC 誘発と共通していると考えられるが, 両負荷の交感神経と迷走神経の興窝・弛緩の順序 は全く逆であり，自律神経系の不均衡といらこと からは両極端を見ていると言える.

また，トレッドミル負荷が aerobic であるのに 対して, 冷水顔面浸水負荷は息をこらえて行ら anaerobic の負荷であること，さらに前者では心 拍出量の增加に伴い心筋自体に負荷がかかるなど の相違点がある.こうした点も両負荷での VPC 誘発に差を生ずることが予想される.

VPC の発生機序は多因子的であり, 単純には 決められないが，両負荷中にみられる VPC は本 質的には異なる機序で誘発されると考えられる. したがって, 冷水顔面浸水負荷でのみ VPC が誘 発される場合があり，また洞停止や伝導障害など が強く現れる症例もあるので，水泳などの水中運
動の可否を決める際に, トレッドミル負荷と併せ て冷水顔面浸水負荷を行うことは術後管理に有用 と思われる.

\section{V. を め}

1）ファロー四徵心内修復術後の患者50例にト レッドミル運動負荷と冷水顔面浸水負荷を行い, 44\%に VPC の誘発を認めた.

2) VPC 誘発群は非誘発群に比し, 術後程 過 年数が長かった.

3）両群で心臓カテーテル検查成績には差が認 められなかった。

4）運動能は誘発群の方がやや劣り, 正常下限 であった。

5）トレッドミル運動負荷と併せて冷水顔面浸 水負荷を行うことは, 術後管理に有用と思われる。

本論文の要旨は第44回日本体力医学会大会(於，札幌) で発表した.

（受付 平成元年11月 8 日）

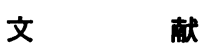

1) Bruce, R. A. and Hornsten, T. R. (1969) : Exercise stress testing in evaluation of patients with ischemic heart disease. Prog. Cardiovasc. Dis., 11, 371.

2) Condry, P., Jain, A., Marshall, R. and Bowyer, A. (1975) : Ventricular tachycardia caused by the diving reflex. Lancet, ii, 1263.

3) Deanfield, J. E., Ho, S., Anderson, R. H., McKenna, W. J., Allwork, S. P. and Hallidie-Smith, K. A. (1983) : Late sudden death after repair of tetralogy of Fallot : A clinicopathlogic study. Circulation, 67, 626-631.

4) Deanfield, J. E., McKenna, W. J., Presbitero, P., England, D., Graham, G. R. and Hallidie-Smith, K. A. (1984) : Ventricular arrhythmia in unrepaired and repaired tetralogy of Fallot. $\mathrm{Br}$. Heart J., 52, 77-81.

5) Dunnigan, A., Pritzker, M. R., Benditt, D. and Benson, D. W. (1984) : Life threatening ventricular tachycardias in late survivors of surgically 
corrected tetralogy of Fallot. Br. Heart J., 52, 198-206.

6) Garson, A., Nihill, M. R., McNamara, D. G. and Cooley, D. A. (1979): Status of the adult and adolescent after repair of tetralogy of Fallot. Circulation, 59, 1232-1240.

7) Garson, A., Gillette, P. C., Gutgesell, H. P. and McNamara, D. G.(1980) : Stress-induced ventricular arrhythmia after repair of tetralogy of Fallot. Am. J. Cardiol., 46, 1006-1012.

8) Gillette, P. C., Yeoman, M. A., Mullins, C. E. and McNamara, D. G. (1977): Sudden death after repair of tetralogy of Fallot: Electrocardiographic and electrophysiologic abnormalities. Circulation, 56, 566-571.

9) Hirschfeld, S., Tuboku-Metzger, A. J., Borkat, G., Ankeney, J., Clayman, J. and Liebman, J.(1978) : Comparison of exercise and catheterization results following total surgical correction of tetralogy of Fallot. J. Thorac. Cardiovasc. Surgery, 75, 446-451.

10) 本田 悲, 砂川博史, 吉井 荋, 溝口康弘, 松本 洋 (1983) : 酸素消費量と心拍数の回帰直線勾配によ る運動耐容能判定. 昭和57年度厚生省心身障害研究 小児慢性心疾患の診断, 治療, 管理に関する研究, 25-30.

11) Horowit z, L. N., Vetter, V. L., Harken, A. H. and Josephson, M. E. (1980) : Electrophysiologic characteristics of sustained ventricular tachycardia occuring after repair of tetralogy of Fallot. Am. J. Cardiol., 46, 446-452.

12) James, F. W., Kaplan, S. and Chou, T. (1975) : Unexpected cardiac arrest in patients after sur. gical correction of tetralogy of Fallot. Circulation, 52, 691-695.

13) James, F. W., Kaplan, S., Schwart z, D. C., Chou, T., Sandker, M. J. and Naylor, V. (1976) : Response to exercise in patients after total surgical correction of tetralogy of Fallot. Circulation, 54, 671-679.
14) Jones, M. and Ferrans, V. J. (1977) : Myocardial degeneration in congenital heart disease : Comparison of morphologic findings in young and old patients with congenital heart disease associated with muscular obstruction to right ventricular outflow. Am. J. Cardiol., 39, 1051-1063.

15) Kavey, R. W., Blackman, M. S. and Sondheimer, H. M. (1982) : Incidence and severity of chronic ventricular dysrhythmias after repair of tetralogy of Fallot. Am. Heart J., 103, 342-350.

16) Keatinge, W. R. and Evans, M. (1961): The respiratory and cardiovascular response to immersion in cold and warm water. Quarterly J. exp. physiol. 46, 83-94.

17) Keatinge, W. R. and Hayward, M. G. (1981): Sudden death in cold water and ventricular arrhythmia. J. Forensic Sciences, 26, 459-461.

18) Mason, R. A. and Likar, I. (1966) : A new system of multiple lead exercise electocardiography. Am. Heart J., 71, 196.

19) Quattlebaum, T. G., Varghese, P. J., Neill, C. A. and Donahoo, J. S. (1976) : Sudden death among post-operative patients with tetralogy of Fallot : A follow-up study of 243 patients for an average of twelve years. Circulation, 54, 289-293.

20) Wessel, H. U., Cunningham, W. J., Paul, M. H., Bastanier, C. K., Muster, A. J. and Idriss, F. S. (1980): Exercise performance in tetralogy of Fallot after intracardiac repair. J. Thorac. Cardiovasc. Surg., 80, 582-593.

21) Wildenthal, K., Leshin, S. J., Atkins, J. M. and Skelton, C. L. (1975) : The diving reflex used to treat paroxysmal atrial tachycardia. Lancet, $i$, 12-14.

22) Woff, G. S., Rowland, T. W. and Ellison, R. C. (1972) : Surgically induced right bundle-branch block with left anterior hemiblock: An ominous sign in postoperative tetralogy of Fallot. Circulation, 46, 587-594. 